\title{
The role of cooperatives in the Georgian wine industry
}

\author{
Levani Kvariani $^{1, a}$ and Sophie Ghvanidze ${ }^{2, b}$ \\ ${ }^{1}$ International School of Economics at Tbilisi State University (ISET), 16 Mikheil Zandukeli Street, Tbilisi, Georgia \\ ${ }^{2}$ Heilbronn Institute for Applied Market Research, Heilbronn University, Max-Planck-Str. 30, 74081 Heilbronn, \\ Germany
}

\begin{abstract}
The potential of the Georgian wine industry is not fully utilized. High fragmentation of agricultural land leads to limited production that restricts farmers' access to capital resources, finances, and markets, and prevents further development of the Georgian wine industry. Grape collectors and wine makers need help to join their capital and efforts, to gain economies of scale in production and marketing by jointly accessing agricultural inputs. This study aims to identify the importance of farmer cooperatives for grape producers in the Georgian wine industry in order to overcome inefficiency in the sector. Furthermore, this research project investigates the barriers and driving forces of smallholder grape farmers or wine makers to join cooperatives. Semi-structured interviews were conducted with stakeholders of the Georgian wine industry in order to assess different perspectives on the importance and benefits of farmer cooperatives in the local context. The interview results permit economic analysis of transaction costs, agency theory and property rights in the context of the nascent cooperative movement in the Georgian wine industry. The interviews revealed that development of agriculture cooperatives in the Georgian wine industry is strongly dependent on both farmer enthusiasm and governmental support. ${ }^{1}$
\end{abstract}

\section{Introduction}

The wine industry is one of the most important sectors of the Georgian economy and the second most important export commodity. Nearly 36,000 households are currently involved in viticulture and grape production [1]. The share of Georgian wine exports is expected to be $6 \%$ of total exports in 2014. After Moldova, Georgia is the second county in the world when it comes to the share of wine in total merchandise exports [2].

Despite the Russian embargo on beverage imports in 2006, Georgia could find new markets and expand its exports. Russia was Georgia's main market for beverage products over the past few decades and along with postSoviet countries, it was the main destination of almost all of Georgia's wine exports. On the contrary, Georgian wine was almost unknown in the U.S. and European countries. In 2006, Georgian wine exports fell by 64 percent compared to the previous year. However, from 2008 to 2012 wine exports grew by 18 percent on average, which was caused by exports expanding to new markets [1]. While the Russian embargo had a significantly negative effect on Georgian wine exports, it gave Georgian wine makers an opportunity to improve the quality of their wines and to penetrate non-CIS countries such as the USA, China, UK, Germany and Poland. Since 2012, after the Russian market for Georgian wine reopened, Russia has been soaking up the majority of Georgia's wine exports.

\footnotetext{
a e-mail: 1.kvariani@iset.ge

b e-mail: Sophie.ghvanidze@hs-heilbronn.de

${ }^{1}$ Paper is based on the thesis submitted in partial fulfillment of the MA requirements at ISET.
}

The export price of Georgian wine per litre has been increasing from the middle of the 1990s, from under 1 dollar to 3.2 dollars in 2011 [2]. Today, the export price of Georgian wine is above the world's average, underpinning its status as a luxury good. Also the share of Georgian wine exports in total merchandise export began rising after the Russian embargo in 2006. In 2007 this number was $2 \%$ and in 2014 the share of wine export in total export became $6 \%$ [1]. Despite this improved performance of the sector in recent years, the Georgian wine industry's potential is not fully utilized due to the sector's low level of efficiency. The amount of grapes and wine that are produced on a unit surface of the vineyard is much lower than the average ratio for New World Wine countries. In Georgia, on one hectare of land it is estimated that about $19 \mathrm{hl}$ of wine can be produced while in the New World Wine countries like Argentina, Australia, or New Zealand the same number is $62 \mathrm{hl}$ of wine [3].

In the Georgian wine industry and, generally, in the agricultural sector, low efficiency is caused by the high fragmentation of agricultural land, which is the result of land reforms undertaken in the 1990s. As a result of these reforms, from 0.802 million hectares of arable land, the average size of land owned by rural households is up to 1 ha, while only about $5 \%$ of households own more than 2 hectares of arable land [4]. Thus, the small scale of production limits farmers' access to capital resources, finances, and markets, and prevents the further development and full utilization of the Georgian wine industry's potential. Additionally, antiquated Soviet-era winemaking equipment is unsuitable for producing wines for international export markets. The fact that Georgian 
farmers are struggling to sell their surplus grapes, along with the practice of wineries increasingly planting their own vineyards indicates that the grape quality of smallholders is not meeting the requirements of exporting wineries [2].

This evidence emphasizes the potential role and importance of farmer cooperatives in the Georgian wine industry, which will help grape collectors and winemakers to join their capital and efforts to overcome the inefficiency in the sector [2]. Furthermore, cooperatives may help farmers gain economies of scale in production and marketing by jointly accessing agricultural inputs and finding buyers.

One of the primary goals of this project is to identify the importance and benefits of farmer cooperatives for grape producers in the Georgian wine industry. Secondly, the study aims to analyse the barriers and driving forces of smallholder grape farmers or wine makers to join farmer cooperatives in order to develop recommendations for nascent grape producers' and winemakers' cooperatives supported by the EU and Georgian Government in 2013. In this framework, 900 cooperatives in total were established, from which approximately 56 are involved in viticulture [5].

Insights from the field of new institutional economics (NIE) will be applied to emphasize the recognized benefits and pitfalls of cooperatives in the Georgian wine industry. This approach integrates the economic analysis of transaction costs, as well as the analyses from the viewpoints of agency theory and property rights.

\section{History of cooperatives}

"A cooperative is an autonomous association of persons united voluntarily to meet their common economic, social, and cultural needs and aspirations through a jointlyowned and democratically-controlled enterprise" [6]. The importance of cooperatives and their contributions to a sustainable economy and livelihood of a population have been increasing steadily around the world. In 2014 the turnover of 2000 cooperatives was 2.6 trillion USD. There has been an increase of $7.5 \%$ ( 2.4 billion USD) since 2010 [7]. At least 250 million people making up $79 \%$ of world's population are involved in cooperatives. 224 million producers execute their activities within the scopes of cooperatives [8]. The largest part of these cooperatives (about 27\%) operates within the agricultural sector. Cooperatives have also become an important source of income for developing countries, e.g. Kenya, Colombia and Indonesia; the majority of cooperative employment is created in $\mathrm{G} 20^{2}$ countries making up $12 \%$ of the working population in these countries [8].

The history of cooperatives begins in the 18th century in Europe, but the roots of cooperatives began in ancient time. It was unimaginable for farmers to operate

\footnotetext{
2 The members of the G20 are Argentina, Australia, Brazil, Canada, China, France, Germany, India, Indonesia, Italy, Japan, Republic of Korea, Mexico, Russia, Saudi Arabia, South Africa, Turkey, the United Kingdom, the United States and the European Union [35].
}

in agriculture without the helps from their neighbours and friends. Cooperation was the main tool for ancient agriculture farmers to sustain themselves and develop their land and harvests. They worked collaboratively, built farms and shared equipment [9]. Due to the infant stage of cooperative development in Georgia, it is hard to imagine that the first cooperative in Georgia was founded in the 19th century with the name "Momchirneoba" [10]. The founder of the cooperative was Ilia Chavchavadze, a Georgian public figure, whose stated that "[c]ooperation is the only way to protect diligent men from furious vultures" [10, p. 1]. The objective of the consumer cooperative was to arrange partnerships and associations in order to help consumers. In the starting stages of cooperation development in Georgia consumer companies, saving-credit partnerships, agricultural and village banks, and worker unions established cooperatives. The main outcome of this development was the establishment of Georgia's Central Union of Consumer Cooperatives that aimed to help populations in rural regions in trade as well as in production and manufacturing of agricultural products [11].

In Georgia the important steps toward developing modern cooperatives were taken in 2013. Until 2013, agricultural cooperatives were virtually non-existent in Georgia, except for a small number of united farmers, who did not legally have the status of cooperatives and thus were unable to use the advantages provided to cooperatives from the government. As a result of the joint efforts of the Parliament and the Government of Georgia, on July 12, 2013, the legislative body enacted the Law of Georgia on Agricultural Cooperatives. In addition, The EU and Georgia entered into an agreement on cooperation in the implementation of the European Neighbourhood Program for agriculture and rural development (ENPARD). In this framework, 905 cooperatives were established, from which approximately 56 are involved in viticulture [5].

\section{The theory of cooperative and their advantages}

The aim of this part of the research study is to investigate the determinants of success and failure in agricultural cooperative development and where cooperatives fit in the Georgian context. In Georgia, before 2013 there were almost no cooperatives in the wine industry (or there were only informal cooperatives). Most grape growers were small-scale farmers. Despite the fact that in recent years many wineries have been developed, only some of them had their own vineyards, and the rest of them have been purchasing grapes from farmers involved in viticulture. According to the Georgian Wine Agency, about 90 percent of wineries own their vineyards, but most of them are dependent on grapes from farmers. In Georgia, family farming is the dominant sector in agriculture. A large part of agriculture products, $88 \%$ are produced by family holdings in Georgia [12]. Over $96 \%$ of the country's grapes are grown on family farms to produce wine for self-consumption or sale grapes to commercial wineries on a non-contractual basis [2]. The fact that family farmers and peasants comprise the majority of the labour force in 
rural areas in Georgia does not mean they have advantages compared to other forms of agriculture organization. The existence of family farming is both the cause and result (a vicious cycle) of farmers' weak ability to create hierarchical organizations in the agricultural sector, such as firms, companies and other legal entities. This is caused by their limited ability to access credit as well as inadequate financial and management skills.

Over the last century, economic theory on cooperatives has developed in two different ways. The first approach is the neoclassical approach toward cooperatives, which views them as firms which maximize profits and minimize costs [12]. This approach is based on some strong assumptions, including: members are treated uniformly, the cooperative accepts total production of its members, the cooperative operates at cost, cooperative members have to supply the whole production to their cooperative and members are price takers [13]. The main problem in this approach is that it does not maximize the welfare of the cooperative members.

Because of its assumptions, neoclassical theory sometimes results in incorrect implications. To correct this, some different approaches have been applied. For instance, some researchers have focused on decision making within the cooperative rather than considering profitmaximizing or cost-minimizing behaviour and eliminating some conditions of the model that are not always satisfied. Taking into account the existence of transaction costs, different types of property ownership and different incentives of decision makers lead to a new way of describing cooperative behaviour in the framework of New Institutional Economics (NIE) [14]. NIE integrates transaction cost economics, agency theory and property rights analyses being important aspects while analysing cooperative's organizational features. For these reasons, the following research study investigates cooperatives from the perspective of New Institutional Economics.

The Neoclassical approach rejects and does not consider transaction costs which are the crucial part of cooperative functionality. Transaction costs in the NIE framework are not zero anymore and they reflect the costs connected with "organizing and transacting exchanges" $[15$, p. 46]. Transaction costs were first mentioned and described with regard to a firm's functionality by economist Ronald Coase [16]. While classical economists argued later that markets allocate resources in the most efficient way, the existence of transaction costs impedes this process. In reality, obstacles to bargaining or poorly defined property rights can prevent resources from being efficiently allocated. Accordingly, this implies that operations within the organization may be more efficient because of their low transaction costs. Therefore, higher market transaction costs motivate economic agents to cooperate in the form of agricultural cooperatives [12].

Agency theory focuses on the different incentives agents face when they make decisions. More formally, "agency theory concerns the problem of agency relationships, which exist whenever one individual, called an agent, acts on behalf of another, called a principal" [15, p. 49]. In terms of cooperatives, agency theory implies that cooperative members are owners of assets (principal) and employee managers (agents) in order to increase their asset value. However, there might be divergence among the interests of owners and managers, which can cause problems.

A property right in a cooperative is defined as the capacity to use some specific asset that the cooperative itself does not own. In order to make a cooperative work properly and to eliminate conflict between members, it is necessary to form an almost complete contract. If the cooperative contract is properly defined, it can avoid the problems which are considered institutional disadvantages of cooperatives such as free rider problem, horizon problem, portfolio problem, control problem, and influence costs problem [14]. But unfortunately, contracts are seldom properly complete and cannot "fully specify the division of value in an exchange relationship for every contingency" [17, p. 72]. Contract form has a great influence on the decision whether to invest in the cooperative.

The potential importance of agriculture cooperatives in the Georgian wine sector can be viewed in terms of its advantages over traditional family farming. Family farms, as an organizational form, have some limitations in the market as they have limited economies of scale in production and marketing and no market power compared to downstream and upstream partners [19]. This problem occurs in the Georgian wine sector, as farmers involved in grape production have limited ability to achieve economies of scale and to gain market power. When they are individually involved in the production process, it is very risky and costly to raise the production of grapes because of limited capital and finances and also uncertainty over whether a full harvest will be realized. They are completely dependent on grape purchases from local traders and wineries. Even if the grape price offered by factories and wineries is not acceptable for them, they have no other choice or marketing channels, and sometimes they sell grapes at prices lower than the costs of production. One way to solve this dependence problem is for Georgian grape producers to make their own wine, but farmers have no guarantee that it will be sold in local or in foreign markets, because of its low competitiveness. Moreover, they cannot meet certain standards, which limit export possibilities.

Cooperatives as an organizational form can make contractual relationships with trade partners and can reduce the costs of searching for trade partners. Furthermore, cooperatives can help farmers achieve economies of scale in production and gain market power. For example, ten farmers buying fertilizers individually for their 1 ha vineyards is more costly than for a cooperative buying fertilizers for its 10 ha vineyard. With regard to bargaining power, cooperatives can purchase business supplies and services as a group with a volume discount. Compared to the individual farmer, cooperative agents become members of wholesale markets, enabling them to purchase services, products and other materials at a discount.

The main benefit of working together is derived from cooperatives' advantages in internalizing the outside cost in the cooperative [18]. The outside cost is a cost paid 
by farmers to the capital renter or for taking services without cooperation. In the case of the wine industry, farmers with different specific assets can join cooperatives. Some of them will own land, vineyards, tractors, or possess management skills and by collaborating they can economize on the costs which would otherwise be paid to the outside person, capital renter. Every cooperative member owns their specific assets and they can avoid the quasi rent to their investment by outside opportunists [18].

Cooperatives also provide opportunities for farmers to achieve a higher level of independence and not to wait for wineries to decide whether they want to purchase a farmer's grapes or not. By internalizing costs and saving their funds, they can accumulate financial resources for the acquisition of wine processing technologies. Due to agricultural products' specific characteristics, such as their perishability, collected grapes require timely processing. Unlike viticulture, other agricultural products, such as nuts or even some citrus fruits, can be stored and marketed several months or even up to a year after being harvested. The features of grapes even further emphasize the need for the establishment of cooperatives to process grapes. As was mentioned previously, family farmers have no bargaining power in the market and they are sometimes forced to accept prices below production costs. Further, cooperatives which do not process their own grapes for wine are dependent on the decision making of wineries. The vertical integration of grape processing and wine production could be considered as one of the most viable ways to decrease the dependence of grape growers on wineries. One big advantage of making the final product is capturing the additional value created through the processing stage. This type of vertical integration would provide opportunities for farmers in cooperatives to access additional financial resources. Secondly, in the long run, established wine grower cooperatives can be transformed into second level wine producing cooperatives, thereby mobilizing all resources to improve production efficiencies and quality of wine, lowering transaction costs and ensuring access to wineries [19].

\section{Methodology}

As part of this research, semi-structured interviews were conducted with the stakeholders of the Georgian wine industry (e.g. government representatives, cooperatives' members, non-member grape growers, and managers of wineries), as well as with policymakers in order to assess different points of view about the importance and benefits of farmer cooperatives as well as the challenges to establish the cooperatives in the local context. The interviews with small-scale wine farmers provide insight into the behaviour of wine farmers as well as into the barriers and driving forces to join farmer cooperatives. The data from these interviews permitted economic analysis of transaction costs, agency theory and property rights in the context of the nascent cooperative movement and the Georgian wine industry.
Semi-structured interview technique is a neutral position between structured and unstructured interview methods and enables to follow discussions partially. At the same time this interview technique gave respondents an opportunity to discuss important and interesting issues of the wine industry in the frame of their current projects.

According to the database of the Agricultural Cooperatives Development Agency (ACDA) of Georgia about 905 new cooperatives were established in Georgia over the last two years. Among them, about 56 cooperatives indicate grape collecting as one of their activities and 16 cooperatives of them are in involved in viticulture as in one and only of their activities [5].

At the initial stage of this research, telephone interviews revealed that some cooperatives had not been previously involved in viticulture. It was part of their future plans, though. Given the small scale of the research, a stratified random sample of Georgian cooperatives was out of the question. Finally, one member of ten cooperatives respectively located in different wine producing regions of Georgia was interviewed. All of the interview partners except one were managing directors of the cooperatives. Considering the high informational level of managing directors on cooperatives as founders and initiators of the cooperatives, we decided to focus on them in the frame of our interviews. The regional coverage includes Kakheti and Racha. Kakheti is the most important wine region in Georgia (60\% of Georgian wine is produced in Kakheti [1]). Interviews were conducted in Racha as well because of scarcity of vineyards and rare grape varieties which are widespread in this wine region. Racha is known by semi sweet wine Kvanchkara stemming from the registered micro zone called Kvanchkara in Racha [31].

10 cooperative members and 10 non-members were interviewed. Non-member farmers were selected randomly. The interviews were recorded and the transcripts from these interviews were subsequently analysed. It could be noted that the interviewed cooperative members had weak knowledge about cooperatives because cooperatives are a relatively new organizational form for collaboration in Georgia. All of the interviewed cooperative members were from cooperatives that were founded sometime over the past 8 months. Very few members had previously worked in their vineyards within this new organizational framework.

In order to assess different point of views about the importance of cooperatives, five interviews with representatives of wine companies were conducted. The companies were chosen from the Georgian National Wine Agency database. As the current research project studies issues on cooperatives and family farms, wineries purchasing grapes from family holdings were selected. Only one of the interviewed wineries purchased all the grapes it uses for wine production from family farmers, three of them have their own wineries.

Two interviews were conducted with representatives of the Agriculture Cooperative Development Agency (ACDA) at the Ministry of Agriculture of Georgia in 
order to get information and statistics concerning current cooperative developments in Georgia.

\section{Results and discussion}

Despite the respondents' low awareness of cooperatives, as caused by their infant position in the agriculture sector the study uncovered a range of problems and opportunities faced by nascent wine growers' cooperatives in Georgia. Information from wine companies and government officials also provides an opportunity to view the problems faced by the wine industry from different perspectives. These results are divided in four themes.

\subsection{Current situation of grape collectors in Georgia}

The interviews revealed that almost every cooperative members and non-members were highly dependent on grape growing activities and vineyards being their main source of income. Some of them mentioned that they were also involved in other agricultural activities, (livestock breeding, poultry, growing plants and other crops) to avoid the entire dependence on their vineyards. They indicated that the only way to sell their grapes is to wineries and factories, and they thus primarily market directly to those businesses. However, there is no guarantee that their grapes would be accepted in the future, presented interview partners. The study also found that farmers have much more agricultural land area than vineyards but because of risk factors this land is used for other crops and pastures. Although, natural disasters were mentioned as a risk factor for their grapes, the most important problem is considered to be that they could only sell their grapes to wineries and factories.

Another big problem which was faced by farmers is limited access to finance. Farmers who mentioned this problem expect government support for taking loans with a low interest rate in order to expand their production. Some cooperative members stated that they established cooperatives for participating in government programs and receiving grants. One cooperative member said that "we have agricultural land, livestock, tractors, and we need finances to begin working in cooperatives; we have capabilities but do not have the means".

Since cooperatives in Georgia are in their initial stage of development, they cannot say how cooperative membership affects their annual costs in the vineyard business. But, they mentioned that the prices of fertilizers are also high for them and they complained about the quality of these fertilizers. Accordingly, from this point of view, we cannot say that they have yet managed to reach economies of scale through cooperative membership, but as they mentioned cooperatives can help to buy fertilizers in large quantities, and they can also achieve a price discount.

As mentioned in Sect. 3 of this paper, cooperatives have a real chance to gain market power toward its downstream and upstream partners. All respondents indicated that they did not yet have any pre-agreements with wineries for their grape sales only one cooperative member stated that he had no problems with grape sales because he had relatives working in local factories. Respondents viewed their dependence on wineries for grape sales as an obstacle for future development. By extending and strengthening cooperatives, they have a good chance to make their own final products and become independent from the wineries. After 2013, nine second level wine producing cooperatives were created in the Georgian wine industry. A Second level cooperative is the union of more than two grape growing cooperatives that produce wine [5]. In an interview, the head of the Agriculture Cooperative Development Agency (ACDA) indicated that in the future they plan to create a third level wine marketing cooperative which will work to create market niche for wines produced by domestic cooperatives. They intend to improve a consciousness among the population that "there is an agricultural product produced by cooperatives that is better in quality than imported product".

Developing cooperatives can also help farmers resolve their grape quality problems. In the interviews, wine company representatives mentioned that they cannot trust Georgian farmers because they use more fertilizers which although increases quantity of grapes, their quality is reduced. This is why Georgian wineries began cultivating their own vineyards while they can control the quality of the grapes. The representative of one winery said that he is ready to make a long term relationship with cooperatives, if they can provide grapes of high quality. Also, forming second level cooperative allows farmers to find their own way to process wine and farmers will thus have higher incentive to increase and then to sustain the grapes' quality in order to sell them at a higher price.

A government program to support Georgian grape growers began in 2012. The government provided a floor price began to buy low quality grapes that had been rejected by wineries and sent these to state-owned wineries. This government intervention had two negative effects. First was fiscal wastage from the government, because the costs were higher than the income from the state owned wineries. Second, it provided a disincentive for grape growers to raise the quality of wine [2].

As the head of the ACDA mentioned, "under this program farmers exploit the government's goodwill by selling low quality grapes. However, if this program stops, farmers will strike, which will be politically unfavourable for the government. From the previous vintage 130 million GEL was accumulated by grape growers in the Kakheti region. I personally met the farmers and suggest to establish wine producing cooperatives, but they rejected it. They prefer to take money from the government annually, rather than making investments and raising the quality of the grapes".

\subsection{Perception of cooperatives by farmers}

The aim of the next block of questions was to understand the level of farmers' awareness about the cooperatives. With regard to what they thought about cooperatives' weak and strong points, only a part of cooperative members surveyed had an answer. They mentioned that the "benefits of working together" was an essence of cooperatives. Some of them also talked about members' importance in 
cooperatives, when they own different assets and possess different skills which can be managed to reach the common goals. But, unfortunately some of the respondents from cooperatives replied that they did not have any responses and viewed the benefits of cooperatives as mainly arising from receiving government support, particularly mini tractors. This was due to the 2013 law, which states that all cooperatives with official agricultural cooperatives status can apply for and receive a mini tractor with a discounted price. The field research for this study found that some farmers (non-members of cooperatives) did not know the meaning of cooperatives and others stated that they had no desire to participate in cooperative. One respondent clearly said that one disadvantage of cooperatives was limited trust. "I envy my neighbour, they envy me. How can we work together? Cooperatives will not work," he argued. Also the study aimed to uncover the reason why did some farmers decide to operate in cooperatives. Unfortunately half of the respondents answered that they wanted to receive tractors from government and they did not even mention their future plans. Even after the reminding them of the opportunity for making their own wines they did not consider it for their future plans. Only two members talked about expanding wine production in the future.

Respondents were also asked about the procedure of cooperative formation. Some of the farmers invested their money, some of them invested their land, while others invested their livestock (measured in money). From the interviews, we found that the registration process was not problematic and was quite easy. But some respondents had problems about land ownership. There are a lot of farmers in Georgia who own agricultural land but they have not registered it formally with the government. So two members said that they registered as a cooperative but they did not have cooperative status from ACDA, because they have no documents that prove their land ownership. This is only one problem which was mentioned by cooperative members about registration.

One of the barriers that may prevent the formation of cooperatives is farmers' low enthusiasm to start a business. Unfortunately, the rural areas of Georgia are dominated by older population as younger people tend to migrate to urban areas. On the question of whether they are going to start working in cooperatives, one middle-aged respondent said: "I am too old to join a cooperative I am counting the days until I die".

As mentioned above, interviews were conducted in Racha region. This region faces many demographic problems. According to National Statistics Office of Georgia each year 400 more people die than are born in Racha. There are villages in Racha region which are disappearing, even though some of them are in a specific micro zone of Kvanchkara (one of the high quality appellation controlled wine). Farmers from this region indicated that the increased market price of grapes Kvanchkara gives them motivation to stay in the villages. Two cooperative members mentioned that cooperatives can give local people chances to get involved in agriculture and stay in the region. Therefore, cooperatives can contribute to social problems in Georgia while it can create jobs in the Georgian agriculture.

\subsection{Relationship among cooperative members}

Based on agency theory, one big problem which arises in cooperatives is conflict between members and managers of cooperatives. But in the Georgian case, as cooperatives are established recently and the number of members is small, everyone is involved equally in cooperative activity and they can be all considered as principals.

According to agency theory, one problem which may arise in cooperatives in comparison to family farms is the potential conflicts between the cooperative members. As cooperative membership increases, this problem may become more harmful and will require good management in order to be prevented. The cooperative members were asked if there were any kinds of conflict between the coop members from the beginning of the cooperative. All respondents stated that this was not the case, with the exception of one cooperative member whose cooperative was bigger than others in terms of members (18 farmers, while the average number of members was five). She mentioned that they were going to dismiss three members from cooperative because of their neutral position and limited involvement in the cooperative. Accordingly, we just can expect more agency relationship problems in Georgian wine industry after the years, when these infant cooperatives begin expanding.

There are three logical reasons why there is currently limited conflict between the members surveyed as part of this research. First, cooperatives are newly established and most members have not yet started collaborating. Second, cooperative membership is on average four members in Racha and six in Kakheti region which is a curiously small number compared to cooperatives around the world. And finally, members of seven cooperatives from interviewed ten cooperatives belong to one family or are very close relatives. Accordingly, the question about their trust of one another was a little awkward, because the answer was positive.

At first glance, the fact that family members are involved in a cooperative is not a problem, but if we think about the reasons for actually forming a cooperative it may very well be. Cooperatives with family members is the same as family farming, with the only difference being the receipt of status as a formally registered agricultural cooperative. Accordingly, they will face the same problems as family farms. Therefore, we can conclude that the aim of forming these cooperatives was primarily to receive benefits from government, in particular from the mini tractor programs. It would be more efficient if in cooperatives will be involved farmers having different complimentary assets by which they will make cost internalization in cooperatives. But, this is connected to trust, which will be a big problem for farmers.

Two respondents from interviewed talked about trust as being a problem in cooperatives. One member who was the founder of the cooperative mentioned that she had a large vineyard but that she does not intend to contribute these vineyards to the cooperative. She mentioned that due to their cooperative's charter, every shareholder has one vote in decision making process despite the share of patronage, so it would be unwise for her to contribute her 
family vineyard and winery to the cooperative. "I am not involved in the cooperative with my vineyards. I have the largest property among the members of the cooperative. And I do not want the cooperative to control my property. Hence, I feel a bit of caution in this case." Also another respondent talked about the "free rider"3 problem, when a cooperative member makes his share in patronage and after that, despite the shirking, the member claims the residual. He mentioned that without making a complete contract we are back to the Soviet-era kolkhoz problem, when "lazy and poor people were happy to join cooperatives, while for a hardworking man it was a load."

Expanding cooperatives means a larger scale effect; an increased number of cooperative members may become the problem for their internal relations, but in Georgia average number of members is about 6.7 people [5]. This prevents agency problems. So this issue will be considered in the future, after beginning cooperative extension and establishing a second level cooperative in the wine industry.

\subsection{Review of the policy environment for agricultural cooperatives in Georgia}

The government has taken significant steps in order to support cooperatives in Georgia: Tax benefits; Possibility to participate in grant programs; new government programs for farmers to access credits; Training and consultations; Aid from the government (for example mini tractors) [5].

Tax benefits can significantly decrease the costs of agricultural cooperatives. Until 2017, cooperatives will be free from the following taxes: income tax, tax on grants, property tax (property, engaged in agricultural activities, will not be taxed) and dividend tax.

There are also possibilities to take part in government grant programs. Nowadays, there are 47 cooperatives involved in grape production and nine in wine production. When the head of the ACDA was asked if these wine producing cooperatives had the same starting position as others, he answered "yes". He said that these cooperatives were involved in the ENPARD project and managed to acquire a grant for creating a second level cooperative. Also, one interviewed cooperative member mentioned that the government suggested that cooperatives should participate in international wine fairs where they can showcase the quality and uniqueness of their products. In combination, these types of opportunities will help wine cooperatives to find export markets.

Despite the important steps toward cooperatives, there are some problems which require more attention. First of all, farmers need more trainings and information from the government and donor organizations about cooperative principles. This study found that the awareness of cooperative principles, as well as the functions and advantages of cooperatives, is fairly unknown among Georgian farmers. Only cooperative members from the Kakheti region mentioned that they were provided with

${ }^{3}$ The term "free rider" refers to a member of a group who obtains benefits from group membership but does not bear a proportional share of the costs of providing the benefits [34, p. 244]. information about trainings, but people from the region of Racha were not. In Racha, of the five cooperative directors that were interviewed, four of them were involved in the regional public sector or had relatives involved in the government structure, from whom they retrieved information about cooperatives and the cooperative movement. Farmers from the villages do not have much information about cooperatives.

Another issue arises when the government attempts to encourage cooperative development. Of course, it is good step when the government helps farmers, but this aid must be reasonable and aimed towards assisting the future development of cooperatives. The government's goal should not be only to increase the number of organizations with the legal status of cooperative; it should try to promote cooperatives, which currently have potential and some business opportunities (when based on realistic business plans). The government should set up a mechanism for limiting the granting of mini tractors. Today, farmers are able to gain cooperative status for $100 \mathrm{Gel}$ and are able to purchase a taking mini tractor at a large discount.

Ideally, the desire of farmers to create a cooperative should be based on the incentive to reduce production and marketing costs and achieve economies of scale or market power. Also, at the initial stage of development, the government can inspire farmers by offering tax benefits to cooperatives. But it is unhealthy for cooperatives in the long run when family members and close relatives establish cooperatives in order to get mini tractors even though they do not have future plans as a cooperative. This cannot be viewed as a success for farmers or cooperatives.

\section{Conclusion}

In Georgia, the boom of agriculture cooperatives began in 2013. Cooperative development was strongly influenced by governmental and EU support. As was revealed in this paper, these cooperatives are in their initial stages of development, and two years is not enough time to conduct a full evaluation of this initiative. However, the Georgian wine industry and Georgian agriculture in general have the potential to find a niche for cooperative agricultural products and this is affirmed by the success of several cooperatives in Georgia.

Unfortunately, in Georgia there are more complications and difficulties preventing development of cooperatives than problems connected to agency and property right theory alone. In their initial stages, cooperatives face many problems that need to be eliminated step by step, such as: poor understandings of cooperatives by farmers, high dependency on government support, weak access to finances, absence of long run future plans, and a lack of trust among farmers.

\section{References}

[1] NSO (National Statistical Office of Georgia): www.geostat.ge (2015)

[2] K. Anderson, Rural Development in Georgia: What Role for Wine Export Growth? http://www . adelaide.edu.au/wine-econ/papers/0112_Geo 
rgian_wine_export_prospects_0612.pdf (2012)

[3] International Organisation of Vine and Wine (2012)

[4] Economic Policy Research Centre: http://eprc. ge/admin/editor/uploads/files/Report_210x 280mm_ENG_WEB.pdf (2013)

[5] ACDA (Agricultural Cooperatives Development Agency): http://acda.gov.ge/ (2015)

[6] ICA (International Co-operative Alliance): http:// ica.coop/ (2015)

[7] World Co-Operative Monitor: http://ica.coop/ es/node/10454 (2014, 2012)

[8] CICOPA (Confederation of Workers' Cooperatives, Social Cooperatives and Social and Participative Enterprises): http://www. cicopa.coop/IMG/pdf / empl_report_fachsheet_cicopa_-_en_web_def_22 -09.pdf (2014)

[9] K. Zimbelman: http: //community-wealth.org/ sites/clone.community-wealth.org/files/ downloads/tool-wheatsville-food-coop.pdf (2007)

[10] Ethic Capital: http://ethiccapital.eu/pdf/ge/ kooperativi\%20statia.pdf (2012)

[11] IBERIA: http://iberia.coop/index.php?do= pages\&id=1\&lang=eng $(2015)$

[12] J. Royer, J. Coop. 28, 1-19 (2014)

[13] R. J. Sexton, J. Coop. 10, 92-99 (1995)

[14] B. Thomas, H. M. Mweneni, J. Dev. Agric. Econ. 3, 695-702 (2011)

[15] J. S. Royer, J. Coop. 14, 44-67 (1999)

[16] R. H. Coase, Economica 4, 386-405 (1937)

[17] M. Sykuta, F. R. Chaddad, J. of Coop. 14, 68-76 (1999)

[18] B. Klein, R. Crawford and A. Alchian, J LAW ECON 21, 297-326 (1978)

[19] Department of Agriculture, Forestry \& Fisheries, Republic of South Africa, A Framework for the Development of Smallholder Farmers Through Cooperative Development: http://www.nda.agric . $\mathrm{za} /$ doaDev/sideMenu/cooperativeandent
erprisedevelopment/docs/FRAMEWORK- $\% 200 \mathrm{~F}$ $\% 20$ SMALL $\% 20$ FARMERS $\% 20 \% 282 \% 29$. pdf (2012)

[20] V. Valentinov, J. Curtiss, Eastern Eur. Econ. 43, 25$45(2005)$

[21] M. L. Cook, F. R. Chaddad, I. Constantine, Advances in Cooperative Theory since 1990: A review of Agricultural Economics Literature (2004)

[22] D. Dzirkvadze, Pathways to Rural Economic Development in Transition Countries (2008)

[23] T. L. Brown, M. Potoski, "Transaction Costs and Contracting," Public Perform. Manag. 28, 326-351 (2005)

[24] I. Yule and C. Eastwood, Farm Policy 12, 33-41 (2015)

[25] R. Capitello and L. Agnoli, A resilient European food industry and food chain in a challenging world (EAAE Seminar 2009)

[26] A. Minguez-Vera, J. F. Martin-Ugedo, N. ArcasNario, Span. J. Agric. Res. 8 pp. 908-924 (2010)

[27] G. Ortmann, R. King, Agrekon 46, 40-59 (2007)

[28] S. Gelashvili, I. Kochlamazashvili, I. Katsia, P. Mamardashvili, The Role of Family Farming in the Sustainable Development of the Agricultural Sector and Poverty Reduction in Georgia (2014)

[29] V. Valentinov, JOIE 3 55-69 (2007)

[30] Transparency International Georgia: http://www. beyondtbilisi.ge/en/content/vine-growers -vs-wine-makers (2014)

[31] Georgian Wine Agency: http://georgianwine. gov.ge/eng (2015)

[32] E. Garnevska, L. Guozhong, N. M. Shadbolt, Int. Food Agribus Man. 14, 69-84 (2011)

[33] Georgian Wine Association, Sector Export Market Development Action Plan: http://www.gwa. ge/upload/file/ENG_Sector_Export_Market_De velopment_Action_Plan.pdf (2011)

[34] R. Albanese, D. D. Van Fleet, Acad Manage Rev. 10 244-255 (1985)

[35] G20: http://g20.org/ (2015) 